\title{
RESEARCH AND INDUSTRIAL PRODUCTIVITY
}

$\mathrm{D}_{\text {tion }}$ URING November 22-25, the Department of Scientific and Industrial Research, in associa. tion with the British Productivity Council, held a working conference on "Research and Industrial Productivity". At its opening luncheon, the Lord President of the Council, Lord Salisbury, stated the national problem, that unless we can work to better advantage, making full use of the knowledge which science can provide, Britain will be unable to maintain its social services and exercise its proper influence in world affairs. The conference itself was directed both to the considerations which determine whether and how quickly a scientific or technological advance can be successfully introduced into industry, and also to the scientific studies by which management and work can be improved so as to yield a higher productivity. The British Productivity Council and many industrial leaders participated, but the body of the conference came mainly from the councils and staffs of research associations, nationalized industries, and a few from government departments.

At the first session. Sir Ben Lockspeiser recalled that King George V, when Prince of Wales, had described the problem in opening the National Physical Laboratory half a century ago. Since then, Sir Ben said, we have developed a greater social conscience and Britain's share in world trade has diminished. To maintain and increase our living standards we must both expand our production and increase its efficiency. We must particularly seek increased efficiency with a minimum of capital investment, because this is a charge on productivity. Similar economy is essential in raw materials. $\mathrm{He}_{\mathrm{e}}$ instanced selenium, where electric and electronic equipment may have a higher claim than brighter milk-bottles. Nor is there a reservoir of technical talent or of labour. Technologists must be used sparingly. The partially or fully automatic factory may go far in meeting labour shortage.

Sir Ewart Smith, vice-chairman (now chairman) of the British Productivity Council, showed that, in spite of recent favourable trends, the rate of increase in productivity in Britain has been, for a considerable period, consistently less than in the United States, although at one time the rates had been the same. We ought to aim at an increase of 10 per cent per annum in the hope that few would fall below 5 per cent and many would achieve 7 or 8 per cent with a reasonable number attaining 10 per cent. $\mathrm{He}$ analysed the functions of research, management and operational study. $\mathrm{He}$ indicated that the research outlook is essentially that which would provide the information and principles on which management decisions should be based and by which improved practice could be instituted on the shop floor. The advantages of automatic operation must be balanced against maintenance work and first cost, but there is the opportunity of transferring labour from routine to interesting work. Although research associations and such bodies cannot do industry's job, yet they can and must provide the basic information, the principles and the encouragement to hasten the industrial revolution which, as Sir Ben had said, is now on the way.
In opening the discussion, Dr. S. Whitehead, chairman of the Committee of Directors of Research Associations, said that, additional to those research associations which have operational departments, many others decentralize such work. He instanced. certain difficulties, such as in making an economic case for change and capital investment, workers' co-operation in research, natural inertia and overindulgence in pride in past achievement and standardization. Nevertheless, research associations must sincerely accept the tasks put by Sir Ben and Sir Ewart both by making the necessary studies and in producing a favourable industrial climate of opinion. Dr. B. K. Blount, deputy secretary of the Department of Scientific and Industrial Research, remarked that the stations of the Department serve many industries and deal with problems of national well-being. $\mathrm{He}$ gave instances to show their insistence on practical application to essential needs. In addition, the Department has central services for studying efficiency and the human element, and to help in all kinds of operational research and information problems. The general discussion turned on the best strategy of approach to industry, and specific problems such as local redundancy.

In a session on materials, Mr. D. A. Oliver, director of the B.S.A. Group Research Centre, said he thought that private enterprise could not unaided exploit mineral resources fully on a long-term plan owing to shortage of risk capital and man-power, insufficient technical resources, lack of information and the uncertainty of world conditions. He proposed that the government should co-operate by the setting up of a minerals advisory bureau, the continuous study of consumer demand and the provision of a national mineral-dressing and process metallurgy laboratory. Although the type of assistance proposed was agreed in the discussion, there were differences as to the mechanism and the institutions which should be responsible. Prof. S. Zuckerman stressed the desirability of living on income rather than capital. Synthetics do not usually replace natural materials, he said: they satisfy new needs and often make large demands upon non-renewable resources such as coal and oil. Conversely, synthesis can shift the burden to renewable resources such as cellulose. If photosynthesis could be understood and made efficient, solar energy and renewable organisms would be much better than chemical factories. These considerations often conflict with short-term profitability, but we must strive towards the best balance, in which both productivity per acre and per man are important. In the discussion the effort was mentioned that has already been made to reduce waste and recover used materials, though the present economic value of recovery does not always represent its ultimate value. Pest destruction could give an immediate saving, and advance in fertilization would increase yield per acre; but in Prof. Zuckerman's view there is a long way to go.

Mr. K. T. Spencer, chief scientific adviser, Ministry of Fuel and Power, recalled that the industrial progress of Britain has been based on cheap coal. An expanded and competitive industrialization demands 
more fuel. At best, nuclear energy will leave for ten years or more an increasing gap between demand and supply. No spectacular increase in coal production has followed mechanization, and the quality has deteriorated. We have provided for increased use of oil ; but greater dependence on imports is ultimately unsatisfactory. We must, therefore, use fuel more efficiently. Railway electrification could save 13 million tons of large coal at the cost of 5 million tons of poor coal. The domestic open fire is condemned anyhow by pollution. Improvements in fuel efficiency have been achieved in collieries, in the ceramics, the iron and steel and the laundry industries; but comparisons show that there is great room for improvement in industry as a whole by the intelligent use of existing data. Research associations could give a lead to industry in this and several have done so ; but industry must respond to advice on this central essential problem irrespective of local incentives, since some industries are large coal users but have a low proportionate fuel cost.

Dr. W. A. MacFarlane, director of the National Industrial Fuel Efficiency Service, described the National Fuel Efficiency Service, which has taken over and expanded the service of the Ministry of Fuel and Power. The Service finds sources of waste, improves operation, makes detailed inspections and full heat and power surveys. He stressed the importance of data on low-pressure steam. Mr. O. F. Thompson's paper dealt with economic factors in the provision of low-cost energy in the future. Research was urged on economic forecasting, capital resources and avail ability, and the effect of taxation. In the discussion, attention was directed to what has been done in collieries, the advantages of pithead electrification, and the reduction between 1920 and 1938 from 1,550 tons to 670 tons needed to generate a million $\mathrm{kWh}$.; since 1938 the firing coal used for ceramics has fallen from nearly 1.25 to 0.4 million tons. Economy is possible in the labour used in obtaining and using fuel. Although water-power, wind-power, terrestrial heat and solar radiation might make no great contribution, they should be used. There is no doubt as to the informed interest in fuel efficiency.

Prof. C. F. Carter, of The Queen's University, Belfast, urged examination of the business hurdles which innovations must surmount-capital investment and risk, the amount and period of profitability, the uncertainties of markets and supplies, the interval required to achieve success. He believes that nowa. days managements are less willing to take risks; but, conversely, with full employment and an inflationary tendency, the risks are less. Dr. R. M. Lodge, research manager of British Nylon Spinners, Ltd., in a paper on the economic factors in the planning of research, referred to economy in the use of scientists, the modern growth of team-work, freedom of atmosphere and the minimum and maximum of expenditure, which are related to the amount of development work. This is much more costly than research and should be more carefully planned, bearing in mind production and sales. Mr. A. H. Wilson, director of research and devolopment, Courtaulds, Ltd., in a paper on the economics of re-equipment, dealt with some of the questions raised by Prof. Carter and discussed the economic effect of discarded plant when changing an existing industry as compared with founding a new industry. Dr. F. M. Lea, director of the Building Research Station, Department of Scientific and Industrial Research, illustrated in the building industry, where there are few large firms and not much capital, the influence of new machines (such as the tower crane) and methods on productivity and the organization to secure it. He showed how these considerations have determined the work of the Building Research Station. Mr. R. T. Eddison, of the British Iron and Steel Research Association, used the example of the handling and transport of iron ore to show how the best compromise can be reached in choosing a method of working, when several different resources are needed which are differently, perhaps oppositely, affected by changes and where the simple criterion of cost might need some qualification. The various discussions on these papers agreed as to the necessity of economic appraisal, but there was divergence as to how it should be done. Similarly, the planning of research against the background of application was admitted, but not the detailed methods : the mention of sponsored research provoked discordance. The opinion was expressed that large concerns in the United States are no more venturesome than British industry. It is clear that the study of the effect of innovation upon production and operation is widespread.

The next two sessions were devoted to the human factor. Mr. R. M. Currie, head of the Central Work Study Department, Imperial Chemical Industries, Ltd., stressed the need for research into work study, which he said is an important tool in management and also is based on the same principles as scientific research; but its application must be direct and speedy. Mr. N. Pleming, chairman and managing director of Associated Industrial Consultants, Ltd., added the further management tools of cost-control and production-planning and control. He thought great improvements could be secured by existing methods, provided co-operation between management and workers is achieved. Dr. C. B. Frisby, director of the National Institute of Industrial Psychology, dealt with the adaptation of equipment and work organization to the anatomical and physiological characteristics of the worker. This leads to psychophysical features which affect the skill of the worker. Lastly, there are psychological aspects which influence the worker's attitude to his task and the satisfaction he gains, and here the relations between workers must be considered.

The two papers from trade union representatives showed some difference of attitude. Mr. L. T. Wright, general secretary, Amalgamated Weavers Associa. tion, believes that productivity is primarily the function of management, which must also convince the workers that they will benefit as human beings from changes: general full employment is not an answer to particular local redundaney. Although Mr. Crawford, chairman of the National Union of Boot and Shoe Operatives, was as emphatic on a proper appeal to workers' natural human qualities, he considered that they can aid management both in planning and in encouraging a favourable response. He examined incentive schemes, rate-fixing and workorganization and gave examples of successful schemes which have been earefully planned and judiciously introduced to the workers. The discussion indicated the general interest in work study, and that the same principles are applicable in many other branches of human activity. Mr. Crawford's opinion that workers would respond to well-conceived and wellexpressed ideas seemed to be accepted.

The summing-up of the conference was by Dr. A. King (D.S.I.R.), Dr. F. C. Toy (Shirley Institute), 
Mr. F. Courtney Harwood (Launderers' Research Association), Mr. S. H. Clarke (Fire Research, D.S.I.R.), the Hon. L. O. Russell (Institute of Management) and Sir Thomas Hutton (Productivity Council). The conference had shown how many resources are available for improving productivity and meeting its technical, its economic and its human problems. All these resources are not everywhere known or used. To overcome this there are two main national agencies. The British Productivity Council, with its decentralized regional organization and circuit system, endeavours to bring management and workers together in every main industrial area, making use of modern methods of presentation. The second agency is provided by the research associations and the Department of Scientific and Industrial Research with its stations. These bodies have valuable contacts with industry since they impinge directly on the particular industrial sectors of which they have expert knowledge. They have already done a great deal and are converted to the objects of the conference. Nevertheless, their structure, especially that of the research associations, permits them to do more ; the value of the conference will depend upon whether it succeeded in establishing that interest in scientific and technological research should not limit the effort to convert industry as a whole to the principles which those attending the conference accepted.

\section{X-RAY APPARATUS AND ASSOCIATED TECHNIQUES}

\section{EXHIBITION IN LONDON}

$\mathrm{A}^{\mathrm{s}}$

$S$ in previous years, an exhibition of X-ray apparatus was arranged in conjunction with the annual congress of the British Institute of Radiology, and was held at the Royal Horticultural Hall, London, during November 23-26. The majority of the exhibits were concerned with medica] applications, both diagnostic and therapeutic, but industrial and scientific instruments were also represented.

Perhaps the most striking feature of modern electronic components and instruments is the way in which improvements in design and in materials have made possible reductions in size and in power consumption. This was well exemplified by much of the X-ray equipment on show. The increased use of oil-immersed components has resulted in compact single-unit power supplies for X-ray tubes, some of them incorporating series triode control valves which permit instantaneous high-tension switching as well as current and voltage stabilization. Another advance in this direction was represented by new oil-immersed high-tension rectifiers the filaments of which consist of thoriated tungsten with a power consumption less than one-third of that of pure tungsten filaments. Another interesting power supply includes a flywheel energy-storage generator which makes it possible to obtain a short-duration X-ray burst of very high intensity without drawing a heavy load from the mains supply.

X-ray tubes themselves have become more mobile; oil-insulated industrial tubes permit underwater radiography, and medical diagnostic and therapeutic tubes are mounted on cradles or above tilting tables which allow them and the patients to be moved automatically or with finger-tip control. Higher intensities are provided by the large range of rotating anode tubes. Another approach to the intensity problem in radiography is provided by the development of more-sensitive detecting devices. A new $\mathrm{X}$-ray film is claimed to be 50 per cent faster than any previous type. Of even greater interest, perhaps, are the new image amplifiers, several examples of which were on show. In these tubes X-ray energy is first converted into light energy by a thin fluorescent screen, in contact with which is a photoelectric surface which, in turn, converts the light into electron emission. The electrons are accelerated by a high potential and focused on a final output screen. By these means the limit of brightness for threshold vision is reduced by a factor of $10: 1$, while the exposure time in fluorophotography is in the ratio of 200:1 as compared with the image produced on a normal fluoroscopic screen.

Artificial radioisotopes are becoming of everincreasing importance both in therapy and in radiography. This fact was reflected in the many instruments on show for the handling and the detection and measurement of high-activity sources. The measuring instruments exhibited ranged from a simple 'nurse-proof' radiation monitor to fully automatic equipment capable of measuring the activities of up to 425 planchet-mounted samples to any desired degree of accuracy without any intervention from a human operator, the results being printed by the machine.

In X-ray therapy the deleterious effects of radiation on healthy tissue are now guarded against, so far as possible, by arrangements of ingenious geometry such as those employed in are irradiation and in moving-beam methods. A new possible way of reducing radiation burns, which may be of great potential importance, is the discovery of the inhibitory effect of cortisone injections on acute X-ray damage to animal tissue. Discoveries like the last, together with apparatus as yet in the experimental stage, were demonstrated in a small scientific section at the exhibition. In general, the main commercial part of the exhibition demonstrated that the X-ray industry is quick in developing new ideas to a production stage.

U. W. ARNDT

\section{THE AGE OF THE UNIVERSE}

$T$

HE Philosophy of Science Group of the British Society for the History of Science last year offered a prize for "the best essay on: What is the logical and scientific status of the concept of the temporal origin and age of the universe?" Twentysix essays were submitted, and a selection of six of these is published as the major portion of the November issue of the British Journal for the Philosophy of Science. The subject is considered from various points of view, the competitors having been asked to "clarify the logical, theoretical and observational aspects of the idea of assigning a quantitative age to the Universe". Naturally the essays vary in the distribution of emphasis between these aspects, and in those published the evidence most relied on ranges from the almost entirely logical to the equally onesided observational kind. The value of the publication as a whole is thus greatly enhanced, and one receives the impression that the editors have made 